\title{
Molecular identification of Mycoplasma synoviae from seroprevalent commercial breeder farms at Chittagong district, Bangladesh
}

Md. Inkeyas Uddin¹, Md. Harisul Abid², Md. Shafiqul Islam³, Tofazzal Md. Rakib³, Ashim Baran Sen², Shah Mohammed Ziqrul Haq Chowdhury ${ }^{4}$, Md. Nurul Anwar ${ }^{5}$ and Kazi Md. Kamaruddin ${ }^{4}$

1. Poultry Research and Training Centre, Chittagong Veterinary and Animal Sciences University, Khulshi - 4225

Chittagong, Bangladesh; 2. Department of Livestock Services, People's Republic of Bangladesh; 3. Department

of Pathology and Parasitology, Chittagong Veterinary and Animal Sciences University, Khulshi - 4225, Chittagong,

Bangladesh; 4. Livestock Division, Bangladesh Agricultural Research Council, Dhaka - 1202, Bangladesh; 5. Port City International University, Chittagong, Bangladesh.

Corresponding author: Mohammed Inkeyas Uddin, e-mail: sarwarprtc@gmail.com,

MHA: harisulabid@yahoo.com, MSI: si.mamun@ymail.com,TMR: rakibtofazzal367@gmail.co, ABS: asimsen@gmail.com, SMZHC: ziqrulhaq@gmail.com, MNA: nurulanwar@yahoo.com, KMK: kazikm54@gmail.com

Received: 12-01-2016, Accepted: 26-08-2016, Published online: 10-10-2016

doi: 10.14202/vetworld.2016.1063-1069 How to cite this article: Uddin MI, Abid MH, Islam MS, Rakib TM, Sen AB, Chowdhury SMZH, Anwar MN, Kamaruddin KM (2016) Molecular identification of Mycoplasma synoviae from seroprevalent commercial breeder farms at Chittagong district, Bangladesh, Veterinary World, 9(10): 1063-1069.

\begin{abstract}
Aim: Worldwide, Mycoplasma synoviae (MS) is an important pathogen of poultry, especially for chicken and turkey. It causes respiratory tract infection and infectious sinusitis. The study was conducted to determine the seroprevalence of MS infection with associated risk factors and identification of MS organism in unvaccinated flocks of commercial breeder farms of the Chittagong district, Bangladesh.
\end{abstract}

Materials and Methods: A total of 365 serum samples were collected and tested for MS using serum plate agglutination (SPA) test for determination of MS seroprevalence. On the other hand, tracheal swabs were collected from each seropositive flocks for polymerase chain reaction (PCR) to determine the presence of MS organism.

Results: Among the farms, the highest prevalence was found to be $69 \%$ and the lowest prevalence was $28 \%$ with the average $60 \%$. The seroprevalence of MS infection in breeder farms was highest $70 \%$ with the flock size $>10,000$ birds, whereas it was lowest $57 \%$ in the flocks ranging from 4000 to 7000 . According to age group, the prevalence was found highest $70 \%$ in $>60$ weeks age group of birds and lowest $42 \%$ in 10-19 weeks group. The seroprevalence of MS in winter season was found as highest as $64 \%$, whereas it was found lowest $60 \%$ in the summer season. There was a statistically significant difference $(p<0.01)$ among the seroprevalence of MS in different breeder farms, flock size, and age groups, but there was no significant $(\mathrm{p}>0.05)$ difference in the winter, summer, and rainy season. To confirm the presence of MS in the samples, PCR test was applied using specific primers to amplify a 214 bp region of the $16 \mathrm{~S}$ rRNA gene of the organism. In PCR, all seropositive flocks showed a positive result for MS.

Conclusion: As the plate agglutination test result showed 100\% similar with PCR result, it can be suggested that agglutination test is better than molecular and culture techniques for MS detection and it is also cheaper and less time-consuming method.

Keywords: breeder farm, Mycoplasma synoviae, polymerase chain reaction, respiratory infection, risk factors, seroprevalence.

\section{Introduction}

Mycoplasmas are widespread in nature and infect a wide range of hosts. Species from the genus Mycoplasma have been isolated (over 110 species) from mammals, birds, reptiles, and fish [1]. Avian mycoplasmosisis caused by several pathogenic Mycoplasmas such as Mycoplasmagallisepticum, Mycoplasmasynoviae (MS), Mycoplasmameleagridis, and Mycoplasmaiowae [2]. Among them, MG and MS are the most important and are listed as notifiable diseases by the OIE. MS infection is primarily a disease

Copyright: Uddin, et al. Open Access. This article is distributed under the terms of the Creative Commons Attribution 4.0 International License (http://creativecommons.org/licenses/by/4.0/), which permits unrestricted use, distribution, and reproduction in any medium, provided you give appropriate credit to the original author(s) and the source, provide a link to the Creative Commons license, and indicate if changes were made. The Creative Commons Public Domain Dedication waiver (http://creativecommons.org/ publicdomain/zero/1.0/) applies to the data made available in this article, unless otherwise stated. of chicken and turkeys but also infects many other domestic and wild birds worldwide $[3,4]$. It causessynovitis, chronic respiratory tract disease, and retarded growth in chickens and turkeys [5].

MS can potentially be present in backyard poultry flocks $[6,7]$. In the breeder flock, the infection causes decreased feed efficiency, poor carcass quality, and suboptimal egg production. As in other poultry producing countries, mycoplasmosis is one of the important disease problems for poultry in Bangladesh, for both commercial and breeder farms [8-10]. In Bangladesh, the prevalence of MS was reported to be 61-67\% [11]. Mycoplasmosis may be diagnosed by different methods such as morphology of causal agents, cultural characteristics; physical, biochemical, and serological properties [8]. In general, Mycoplasma infections are diagnosed using serological methods and eventually by polymerase chain reaction (PCR) [12]. Various serological tests have been developed for detection of 
antibodies against MS [13]. The serum plate agglutination (SPA) test could be used as a tool for quick detection of avian Mycoplasma infection [14]. Besides, tracheal and cloacal swabs are also used in the identification of the agent using PCR [15]. MS infections are often associated with other diseases, so the use of advanced techniques such as PCR is a tool of great importance in diagnosis of MS infections with achieving greater accuracy, which leads to a better understanding of the pathogen affecting avian populations [16]. Control of pathogenic MS consists of three general approaches: Maintaining flocks free of infection, medication, or vaccination. The most effective method of controlling MS infection is regular monitoring of the flocks and eliminating the positive flocks [17]. Chittagong is considered to be a poultry zone with a number of breeder farms in the area, but less emphasis has been given to diagnose the Mycoplasma infection in breeder farm, and no work has been reported on MS in this area. The aim of the study was to determine the prevalence ofMS using SPA and molecular method in the breeder farms of the Chittagong district.

\section{Materials and Methods}

\section{Ethical approval}

Not required for this study.

\section{Study area and season}

The study was conducted in the breeder farms of Chittagong District from January 2012 to December 2012, encompassing summer (March to May), winter (November to February) and rainy (June to October) seasons. The research work was carried out in the Poultry Research and Training Centre (PRTC) Laboratory, Chittagong Veterinary andAnimal Sciences University, Khulshi, Chittagong.

\section{Sampling}

Sample size was determined using the standard formula adopted from Araoye [18], Iloh et al. [19] $\mathrm{N}=\mathrm{z}^{2} \mathrm{pq} / \mathrm{d}^{2}$ Where, $\mathrm{N}=$ sample size, $\mathrm{z}=1.96$ confidence interval, $p=$ prevalence, which is $61 \%$ for MS [11], $\mathrm{d}=5 \%$ allowable error, $\mathrm{q}=1-\mathrm{p}$. Using this formula, the minimum sample size was calculated to be around 365 for the breeder chickens for the Chittagong district in Bangladesh.

A total of 368 blood samples were randomly collected from the breeder farms where the birds were not vaccinated against MS. About 1-1.5 ml of blood was collected from wing vein using a fresh disposable plastic syringe ( $3 \mathrm{ml}$ volume) for each bird. The blood samples were kept at room temperature for about $1-2 \mathrm{~h}$ and then centrifuged at $1500 \mathrm{rpm}$ for $10 \mathrm{~min}$ using a bench centrifuge (VELOCITY $18 \mathrm{R}^{\mathrm{TM}}$ refrigerated centrifuge). A clean straw-colored serum was seen up and around the clotted clump that was poured into a labeled Eppendorftube and stored at $-20^{\circ} \mathrm{C}$ until used.

\section{SPA test}

The SPA test was conducted using the method as described in the work of Sarkar et al. [20]. In this study, crystal violet stained MS commercial antigen (Bio Vac.) was used. A $25 \mu 1$ volume of antigen was placed side by side on a glass plate with $25 \mu 1$ of the serum using a micropipette. The serum and the antigen were then mixed well by stirring with a small toothpick followed by gentle rocking. Results were read within 2 min over a light source. In positive cases, granules were formed slowly which could be seen during rocking. In the negative cases, no such granules were formed. All SPA results were recorded as,+++ , and +++ denoting, respectively, as small, medium, and large to very large clumps. The strength of the agglutination reaction was measured as $-=$ No clumps, no background clearing; $+=$ Small clumps, no background clearing; $++=$ Medium sized clumps, almost complete background clearing; $+++=$ Large clumps, complete background clearing.

\section{Molecular identification}

For PCR test, tracheal swab samples were taken randomly from each of the non-vaccinated seropositive breeder flocks among the studied breeder farms. Swab samples were stored in Phosphate buffered saline (PBS) at $4^{\circ} \mathrm{C}$ overnight. DNA extraction was than performed according to the protocol adopted by Ogino et al [21].

\section{DNA extraction}

DNA was extracted using the protocol described in brief [21]. Swab samples suspended in $1 \mathrm{ml}$ of PCRgrade PBS in a $1.5 \mathrm{ml}$ Screw-cap Eppendorf tube. The suspension was centrifuged for $30 \mathrm{~min}$ at $14,000 \mathrm{~g}$ at $4^{\circ} \mathrm{C}$, and supernatantwas carefully removed with a Pasteur Pipette. The remaining pellet was suspended in $25 \mu \mathrm{l}$ PCR-grade water. The tubes with the contents were boiled for $10 \mathrm{~min}$ and then placed on ice for $10 \mathrm{~min}$. Then, centrifugation at $14,000 \mathrm{~g}$ for $5 \mathrm{~min}$, the supernatant containing the DNA was used as template DNA for PCR.

\section{$P C R$}

The reaction mixture was prepared in a separate clean area using a set of dedicated pipettes. For one $50 \mu 1$ PCR reaction, the mixture containing $\mathrm{H}_{2} \mathrm{O}$ ultrapure $35.75 \mu 1,10 \times$ PCR Buffer $5.00 \mu 1$, Dntp $(10 \mathrm{Mm})$ $1.00 \mu \mathrm{l}$, forward primer $(20 \mathrm{pmole} / \mu \mathrm{l}) 0.50 \mu \mathrm{l}$, reverse primer $(20 \mathrm{pmole} / \mu \mathrm{l}) 0.50 \mu \mathrm{l}$, taq $(5 \mathrm{U} / \mu \mathrm{l}) 0.25 \mu \mathrm{l}$, and $\mathrm{MgCl}_{2}(50 \mathrm{Mm}) 2.00 \mu \mathrm{l}$ (Promega $\left.{ }^{\circledR}\right)$. A $45 \mu \mathrm{l}$ volume of the reaction mixture was dispensed into each PCR tube. The tubes were then taken to another clean area where the appropriate DNA samples $(5 \mu 1)$ were added to each tube. Positive and negative controls were used in each run. The thermal profile consisted 40 cycles of initial denaturation at $94^{\circ} \mathrm{C}$ for $5 \mathrm{~min}$, denaturing at $94^{\circ} \mathrm{C}$ for $30 \mathrm{~s}$, annealing at $55^{\circ} \mathrm{C}$ for $30 \mathrm{~s}$, and extension at $72^{\circ} \mathrm{C}$ for $1 \mathrm{~min}$, followed by final extension $72^{\circ} \mathrm{C}$ for $5 \mathrm{~min}$ and final storage at $4^{\circ} \mathrm{C}$. A negative control did not contain template DNA and consisted of PCR master mix, sets of primers, and nuclease free water. Primer used in this study was previously reported by 
OIE [13] and Pérez et al. [22]. Details of the primers used for PCR are shown in Table-1.

\section{Gelelectrophoresis}

PCR product was analyzed by electrophoresis on $1.5 \%$ agarose gel, containing SYBR green for $30-40 \mathrm{~min}$ at $100 \mathrm{v}$, and examined under ultraviolet (UV) light using a UVlight transilluminator (UV Star, Biometra, Germany).

\section{Statistical analysis}

All data were entered into a spreadsheet program (Excel 2007, Microsoft Corporation) and transferred to Stata 11 (Intercooled Stata 11, Stata Corporation, College Station, Texas, USA) for analysis. The difference in the seroprevalence rate of MS in between variables was shown using Chi-square test.

\section{Results}

To study the seroprevalence of MS, SPA test was done based on the previous research works where the sensitivity and specificity of SPA test were compared with the culture, PCR, and various commercial enzyme-linked immune sorbent assay tests [23-25]. In the present study, sera samples were collected from the different breeder farms of Chittagong district where the birds were not vaccinated against MS. After collection of the samples, SPA test was done followed by PCR as a confirmatory test for identification of the organism as the culturing of MS is costly, time-consuming, and inconclusive $[24,26]$. Details of the seroprevalenceof MS with different risk factors are shown in Table-2.
Table-2 shows that the seroprevalence of MS was highest $(69 \%)$ in farm 5 among the different breeder farms under the study. The seroprevalence was found to be lowest $(28 \%)$ in the farm 3 . There was statistically significant $(\mathrm{p}<0.01)$ differences in the seroprevalence of MS with farm 3 to other breeder farms under study in Chittagong district.

The seroprevalence of MS infection in the breeder farms was highest $(70 \%)$ with the flock size of $>10,000$, whereas it was lowest $(57 \%)$ with the flock size ranging between 4000 and 7000 birds. From this result, it became evident that higher the flock size greater the seroprevalence of MS in the breeder farms of Chittagong district. There was a statistically significant $(p<0.01)$ variation in terms of seroprevalence of MS among the different flocks of the breeder farms in Chittagong district (Table-2).

As shown in Table-2, the seroprevalence of MS in breeder farms of Chittagong district was lowest $(42 \%)$ in the lowest age group (10-19 weeks) and highest (70\%) in the highest age group ( $>60$ weeks) of birds. This gives an indication that as the age of birds advanced the seroprevalence of MS infection in the breeder farms was also advanced. There was a statistically significant $(p<0.01)$ difference in the seroprevalence of MS in the different age groups of birds from various breeder farms of Chittagong district.

The seroprevalence of MS in the winter season was found as high as $64 \%$, whereas it was lowest $(60 \%)$ in the summer season. However, the difference in the seroprevalence of MS was statistically not

Table-1: Details of the primers used for PCR.

\begin{tabular}{lllcr}
\hline Primer name & Gene & Nucleotide sequence (5"-3") & Product size & Reference \\
\hline MS-F & 16S r & 5'GAG AAG CAA AAT AGT GAT ATC A-3' & 214 bp & [22] \\
MS-R & RNA & 5'CAG TCG TCT CCG AAG TTA ACA A-3' & & \\
\hline
\end{tabular}

$\mathrm{PCR}=$ Polymerase chain reaction

Table-2: Seroprevalence of M.synoviae with different risk factors.

\begin{tabular}{|c|c|c|c|c|c|c|}
\hline \multirow[t]{2}{*}{ Risk factors } & \multirow[t]{2}{*}{ Level of risk factors } & \multicolumn{4}{|c|}{ Positive percentage } & \multirow[t]{2}{*}{ Significance value } \\
\hline & & + & ++ & +++ & Total & \\
\hline \multirow[t]{6}{*}{ Farm } & 1 & 19.51 & 28.05 & 14.63 & 62.19 & 0.002 \\
\hline & 2 & 23.40 & 25.53 & 17.02 & 65.95 & \\
\hline & 3 & 18.37 & 4.08 & 6.12 & 28.57 & \\
\hline & 4 & 35.62 & 19.18 & 10.96 & 65.76 & \\
\hline & 5 & 32.69 & 21.15 & 15.38 & 69.22 & \\
\hline & 6 & 29.63 & 20.92 & 13.59 & 64.14 & \\
\hline \multirow[t]{3}{*}{ Flock size } & $4000-7000$ & 24.32 & 20.5 & 11.49 & 56.76 & 0.004 \\
\hline & $7001-10,000$ & 33.33 & 18.18 & 8.33 & 59.84 & \\
\hline & $>10,000$ & 20.45 & 25.00 & 25.00 & 70.45 & \\
\hline \multirow[t]{6}{*}{ Age } & $10-19$ weeks & 25.35 & 12.68 & 4.23 & 42.26 & 0.000 \\
\hline & 20-29 weeks & 21.15 & 15.38 & 25.00 & 61.53 & \\
\hline & 30-39 weeks & 38.89 & 19.44 & 4.17 & 62.50 & \\
\hline & 40-49 weeks & 22.22 & 28.89 & 13.33 & 64.44 & \\
\hline & 50-59 weeks & 20.00 & 31.67 & 16.67 & 68.34 & \\
\hline & >60 weeks & 27.94 & 20.59 & 22.06 & 70.59 & \\
\hline \multirow[t]{3}{*}{ Seasons } & Summer & 30.77 & 16.67 & 12.18 & 59.62 & 0.229 \\
\hline & Winter & 26.44 & 27.59 & 10.34 & 64.37 & \\
\hline & Rainy & 21.60 & 21.60 & 17.60 & 60.80 & \\
\hline
\end{tabular}

M.synoviae=Mycoplasma synoviae 
significant ( $p>0.05$ ) for the winter, summer, and rainy seasons in the breeder farms of Chittagong district.

The large clumps may be due to the presence of the highest concentration of antibody. Sera samples forming large clumps were also reacted faster than other small clump forming sera samples. As shown in Table-2 and Figure-1, the large and very large sized clumps in SPA test were found in the highest percentage $(17.02 \%)$ in farm 2 , and the medium sized clums were found highest $(28.05 \%)$ in farm 1 . The small sized clumps were found in the highest percentage $(35.62 \%)$ in farm 4 . It is to be mentioned also that in farm 3 the strength of agglutination reaction was lower than the remaining other farms.

The highest seroprevalencewas found $69.22 \%$ and lowest was $28.57 \%$ among the breeder farms under study in Chittagong district. The overall seroprevalence of MS was found $60 \%$.

The PCR product of MS for the respective primer (16S rRNA gene) was migrated as 214 bp band on agarose gel (Figure-2). In the PCR test, each of the farms under study showed a positive result. Therefore, it may be concluded that every seropositive farms under study were harboring MS infection.

\section{Discussion}

In this study, only positive samples were used to analyze data because the all the seronegative samples were found negative in PCR, so we can assume that agglutination test is quite cheapest and easiest method than PCR in MS diagnosis. In this study, only $16 \mathrm{~S}$ RNA reported primer was used for screening the MS and compares the test result with agglutination test primarily.

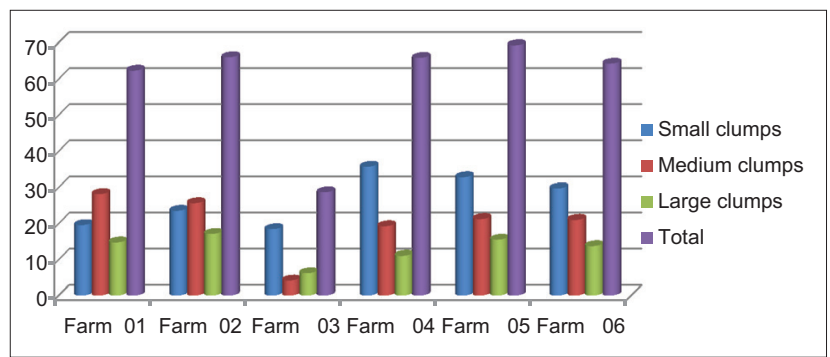

Figure-1: Strength of the agglutination reaction in (serum plate agglutination) test in different breeder farms.

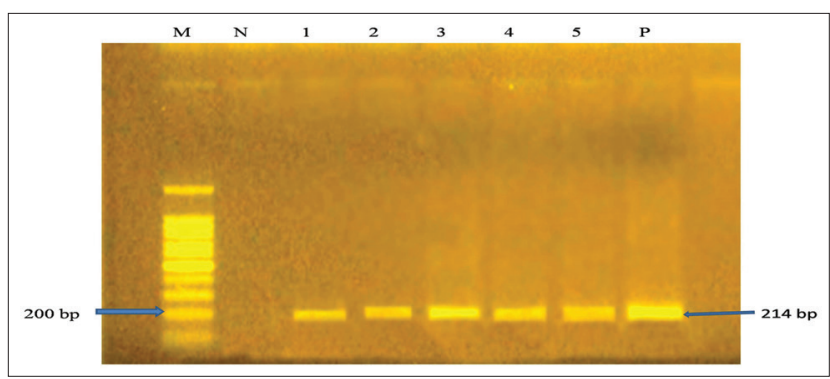

Figure-2: Results of polymerase chain reaction for $16 \mathrm{~S}$ rRNA gene of Mycoplasma synoviae; Lane M: 100 bp ladder; Lane N: Negative control; Lane 1-5: 16S rRNA gene-sized (214 bp) amplicon; Lane P: Positive control.
MScan be transmitted vertically and horizontally [2]. Results show that the highest (69\%) and lowest $(28 \%)$ prevalence of MS infection was found in farm 5 and 3, respectively. In farm 3, strict "culling of flocks" was practiced that probably reduced vertical transmission of Mycoplasma to the offspring resulting in lowest prevalence. This finding is in agreement with a similar study demonstrated by Feberwee et al. [27], who reported the lowest MS infection $(6 \%)$ in farms where intensive culling was practiced. The high prevalence $(69 \%)$ of MS infections in breeder stock can be explained by the frequent occurrence of multiple age housing and lower biosecurity standards in farm 5, and this argument again has been supported by the study of Stipkovits and Kempf [2] and Kleven et al. [28]. The higher prevalence of Mycoplasma infection might also be due to the replacement of breeding stock with the progeny of the same flock [8]. Intensive nature of poultry farming also affords opportunity for recycling of the pathogens due to population density [14] that might also explain why the breeder farms under study showed the higher prevalence of MS. The other factors that contribute MG infection are poor ventilation, contamination of litters and no restriction on the movement of the technical personnel, visitors, and such other persons as well as other biosecurity measures [29]. No relation was found between a special breed and occurrence of MS infection status [25,30]. Size of flock was found not to have much effect up to the flock size of 10,000 which conforms with the work of Seifi and Shirzad [25], who reported as saying that size of flock does not have an impressive effect in appearance of MS infection, but this problem is worse in the greater sizes of flocks. Our findings of large flocks having $>10,000$ birds showing seroprevalence of $70 \%$ and smaller sized flocks of bird (4000-7000) showing prevalence of $57 \%$ is in agreement with Heleili et al. [31] and Talha [32], who showed a higher infection rate $(76.97 \%)$ in large flocks (18,000 birds) in comparison to small flocks (500-1000 birds) [25] showed the highest infection rate $(57 \%)$ in large scale flocks $(>40,000$ birds $)$ in comparison $(41.9 \%)$ to small (up to 30,000 birds) flocks. Similar report was demonstrated by Catania et al. [30]. This variation may be due to horizontal transmission of infection, deficiency in management, and low biosecurity [8,14,27,29].

Age is a very important parameter influencing the incidence of mycoplasmosis $[9,33,34]$. The seroprevalence of MS was found higher in the advancing age groups. The highest (70\%) and lowest (57\%) prevalence of MS was found in age groups $>60$ weeks and 10-19 weeks, respectively. This finding was in agreement with other research groups. Feberwee et al. [27] reported that the seroprevalence of MS was highest (60\%) in age group above 51 weeks. The same type of findings with $12 \%$ seroprevalence in age group 10-20 weeks and 43\% seroprevalence in age group above 60 weeks was suggested by Seifi and Shirzad [25] and Mukhtar et al. [35]. The prevalence 
study of Yegani and Korver [36], which was based on the detection of MS antibodies in eggs, reported a prevalence of $78.6 \%$ in commercial layer flocks in East England. In another study of Qasem et al. and Hammouda et al. [37,38], 87\% prevalence of MS was found in commercial layer flocks in Southern California. The infection was associated with older flocks that had been molted or frequently medicated. Stipkovits and Kempf, [2] Bonneaud et al., [39] and David et al. [40] suggested that it may be due to more exposure of MS organism to birds as their age advances because MS can be transmitted both vertically and horizontally. In the present study, seasonal variation for the prevalence of MS was observed. However, the statistical analysis showed no significant $(p>0.05)$ variation among the prevalence of seasons; the seroprevalence was highest $(64 \%)$ in winter and lowest $(60 \%)$ in summer (Table-2). This finding was in agreement with Heleili et al., [9] Seifi and Shirzad [25], Hossain et al., [41] and Sikder et al. [42] where they suggested that higher prevalence in winter might be due to the influence of cold weather. However, this finding was not in agreement with the findings of Heleili et al. [31] and Arbelot et al. [43] where they found that the seroprevalence was higher in summer season. In the present study, the overall seroprevalence of MS was (60\%) which is in agreement with Giasuddin et al [11]. He reported the seroprevalence of MS in Bangladesh to be 61-67\%.

For eradication of MS infection, rapid and accurate identification of MS is of great importance and molecular methods such as the PCR have been developed to improve this. Earlier MS-specific PCRs were based on the 16S rRNA gene [44,45], and more recently, some have been based on hemagglutinin genes $[15,46]$. In this study, species-specific primers of Pérez et al. [22] were used. These MS primers were selected from the 16S rRNA gene. The PCR method of Garcia et al. [44] used by Pourbakhsh et al. [24] is also based on the 16S rRNA gene. The PCR used in this study was species specific and had been used in recent years by other workers successfully $[22,24]$. In this study, all seropositive farms showed a positive result in PCR. With these findings, it may be concluded that those farms were harboring MS infection. It is possible to determine the presence of serum antibody using SPA test but not possible to determine whether the antibody is due to active infection or vaccination. To determine active infection or presence of MS, either organism culture or PCR test can be used. However, Mycoplasma being a facultative organism its culture is time-consuming and laborious [47]. On the other hand, PCR is comparatively easy, less time-consuming, and most reliable diagnostic tool. Therefore, PCR was adopted in this study for confirmation of the presence of MS in the infection $[26,48]$.

These results strongly support the use of this PCR assay as an efficient alternative or supplement to culture and serological identification, which are labor-intensive, extremely time-consuming, and often provide confusing results. Overall, it is suggested that the PCR could be an alternative method for accurate identification of the MS infection, especially in breeder chicken flocks [49].

MS infection was found to be prevalent among the poultry breeder farms in Chittagong district. The overall seroprevalence of the disease was $60 \%$ with the highest and lowest rate of $69 \%$ and $28 \%$, respectively. The prevalence varied significantly among the different farms due to varied farm conditions, age groups, and flock sizes; however, there was not any seasonal variation.

The prevalence rate of MS that has been observed in this study may not be true for the whole country. To determine the actual prevalence rate on MS in Bangladesh, a detail study covering the whole country may be conducted. Economic impact due to MS infection in poultry and the strain of MS involved was not assessed through this study. For proper control of the disease, strain identification of MS has a statistically significant value. Further study is needed to be conducted to have all those questions answered.

\section{Authors' Contributions}

MIC, KMK: Designed the research work and provided the technical guidance. MHA and MSI: Conducted the research work. SMZHC, ABS, and MNA: Provided necessary help during research. MIC and KMK: Helped in laboratory analysis. MNA and TMR: Revised the manuscript. All authors read and approved the final manuscript.

\section{Acknowledgments}

This study was undertaken in Poultry Research and Training Centre (PRTC) Laboratory, CVASU. Author would like to thanks all the staff of the PRTC laboratory specially Shawkat Ullah and special thanks to Mr. Kazi Md Rokan Uddin, technical officer at PRTC, for their help during laboratory work.

\section{Competing Interests}

The authors declare that they have no competing interest.

\section{References}

1. Elgnay, F. and Azwai, S. (2013) Seroprevalence of Mycoplasma synoviae and Mycoplasma gallisepticum in one day old broiler chickens in Libya. J. Anim. Poult. Sci., 2(1): 11-18.

2. Stipkovits, L. and Kempf, I. (1996) Mycoplasmoses in poultry. Rev. Inform. Sci. Technol., 15(4): 1495-1525.

3. Bradbury, J.M., Abdul-Wahab, O.M.S., Yavari, C.A., Dupiellet, J.P. and Bové, J.M. (1993) Mycoplasma imitans sp. Nov. Is related to Mycoplasma gallisepticum and found in birds. Int. J. Syst. Bacteriol., 43(4): 721-728.

4. Ghorashi, S.A., Kanci, A. and Noormohammadi, A.H. (2015) Evaluation of the capacity of PCR and high-resolution melt curve analysis for identification of mixed infection with Mycoplasma gallisepticumstrains. PLoS One, 10(5): e0126824.

5. Feberwee, A., De Wit, J. and Landman, W.J. (2009) 
Induction of eggshell apex abnormalities by Mycoplasma synoviae: Field and experimental studies. Avian Pathol., 38(1): 77-85.

6. McBride, M.D., Hird, D.W., Carpenter, T.E., Snipes, K.P., Danaye-Elmi, C. and Utterback, W.W. (1991) Health survey of backyard poultry and other avian species located within one mile of commercial California meat-turkey flocks. Avian Dis., 35(2): 403-407.

7. Al-Shekaili, T., Baylis, M. and Ganapathy, K. (2015) Molecular detection of infectious bronchitis and avian metapneumoviruses in Oman backyard poultry. Res. Vet. Sci., 99: 46-52.

8. Hossain, K., Ali, M. and Haque, M. (2007) Seroprevalence of Mycoplasma gallisepticum infection in chicken in the greater Rajshahi District of Bangladesh. Bangladesh J. Vet. Med., 5(1): 9-14.

9. Heleili, N., Mamache, B. and Chelihi, A. (2011) Incidence of avian mycoplasmosis in the région of Batna, Eastern Algeria. Vet. World, 4(3): 101-105.

10. Jalil, M. and Islam, M. (2012) A cross-sectional study for Mycoplasma gallisepticum antibodies in non-vaccinated commercial layer birds in Khulna District. Bangladesh $J$. Vet. Med., 8(2): 93-96.

11. Giasuddin, M., Sil, B., Alam, J., Koike, I., Islam, M. and Rahman, M. (2002) Prevalence of poultry diseases in Bangladesh. J. Biol. Sci., 2(4): 212-213.

12. Godoy, A. (1999) Prevalence of Mycoplasma gallisepticum and Mycoplasma synoviae in laying hens. Central University of Venezuela (UCV) School of Veterinary Sciences (FCV). Thesis for the degree of Master Scientarum in Veterinary Medicine, Microbiology mention. Ex. 757. UCV-FCV. Maracay.

13. OIE. (2008) Manual of Standards for Diagnostic Tests and Vaccine. Paris: World Organization for Animal Health. Available from: http://www.oie.int. [Last retrieved on 2015 Jul 07].

14. Pradhan, M. (2002) Studies on avian mycoplasmosis: Prevalence, isolation, characterization and antigenic properties. Ph. D. Thesis Submitted to the Departement of Microbiology and Hygiene, Faculty of Veterinary Science, Bangladesh Agricultural University, Mymensingh, Bangladesh.

15. Hong, Y., García, M., Leiting, V., Benčina, D., DufourZavala, L., Zavala, G. and Kleven, S.H. (2004) Specific detection and typing of Mycoplasma synoviae strains in poultry with PCR and DNA sequence analysis targeting the hemagglutinin encoding gene vlhA. Avian Dis., 48(3): 606-616.

16. Raviv, Z and Kleven, S.H. (2008) The Development of Diagnostic Real-Time Taqman PCRs for The Four Pathogenic Avian Mycoplasmas. Av. Dis. 53(1):103-107.

17. Kleven, S. (2008) Mycoplasmosis. In: Saif, Y., Fadly, A., Glisson, J., McDougald, L., Nolan, L., Swayne, D., editors. Diseases of Poultry. $12^{\text {th }}$ ed. Blackwell Publishing, Iowa State University Press, USA, Ames. p805-807.

18. Araoye, M. (2004) Sample Size Estimation, Research Methodology with Statistics for Health and Social Sciences. Nathadex Publishers, Ilorin. p55-81.

19. Iloh, G., Amadi, A., Nwankwo, B. and Ugwu, V. (2011) Obesity in adult Nigerians: A study of its pattern and common primary co-morbidities in a rural Mission General Hospital in Imo state, South-Eastern Nigeria. Nig. J. Clin. Pract., 14(2): 212-218.

20. Sarkar, S., Rahman, M., Rahman, M., Amin, K., Khan, M. and Rahman, M. (2005) Sero-prevalence of Oinfection of chickens in model breeder poultry farms of Bangladesh. Int. J. Poult. Sci., 4(1): 32-35.

21. Ogino, S., Munakata, Y., Ohashi, S., Fukui, M., Sakamoto, H., Sekiya, Y., Noormohammadi, A.H. and Morrow, C.J. (2011) Genotyping of Japanese field isolates of Mycoplasma synoviae and rapid molecular differentiation from the MS-H vaccine strain. Avian Dis., 55(2): 187-194.
22. Pérez, V., Brett, M., Moscoso, H., Jaramillo, C., Godoy, A., Marcano, E., Saume, E., Garcia, K., Fragozzo, J. and Perozo, L. (2011) Isolation and molecular characterization of Mycoplasma gallisepticum and Mycoplasma synoviae in broiler breeders and commercial layers in Venezuela. xxii-latin-american-poultry-congress.

23. Feberwee, A., Mekkes, D., De Wit, J., Hartman, E. and Pijpers, A. (2005) Comparison of culture, PCR, and different serologic tests for detection of Mycoplasma gallisepticum and Mycoplasma synoviae infections. Avian Dis., 49(2): 260-268.

24. Pourbakhsh, S., Shokri, G., Banani, M., Elhamnia, F. and Ashtari, A. (2010) Detection of Mycoplasma synoviae infection in broiler breeder farms of Tehran province using PCR and culture methods. Arch. Razi Inst., 65(2): 75-81.

25. Seifi, S. and Shirzad, M. (2013) Risk factors and seroprevalence of Mycoplasma synoviae infection in broiler breeder farms. Acta Sci. Vet., 41: 1139.

26. May, M. and Brown, D.R. (2011) Diversity of expressed vlhA adhesin sequences and intermediate hemagglutination phenotypes in Mycoplasma synoviae. J. Bacteriol., 193(9): 2116-2121.

27. Feberwee, A., de Vries, T.S. and Landman, W.J. (2008) Seroprevalence of Mycoplasmasynoviae in Dutch commercial poultry farms. Avian Pathol., 37(6): 629-633.

28. Kleven, S., Rowland, G. and Olson, N. (2008) Mycoplasma synoviae infection. In: Saif, Y., Fadly, A., Glisson, J., McDougald, L., Nolan, L. and Swayne, D., editors. Diseases of Poultry. 12 $2^{\text {th }}$ ed., Vol. 10. Blackwell Publishing, Iowa State University Press, USA, Ames. p845-856.

29. Dulali, R. (2003) Seroprevalence and pathology of mycoplasmosis in sonali chickens. MS Thesis, Submitted to the Department of Pathology, Faculty of Veterinary Science, Bangladesh Agricultural University, Mymenisngh.

30. Catania, S., Bilato, D., Gobbo, F., Granato, A., Terregino, C., Iob, L. and Nicholas, R.A. (2010) Treatment of eggshell abnormalities and reduced egg production caused by Mycoplasma synoviae infection. Avian Dis., 54(2): 961-964.

31. Heleili, N., Ayachi, A., Mamache, B. and Chelihi, A.J. (2012) Seroprevalence of Mycoplasma synoviae and Mycoplasma gallisepticum at Batna commercial poultry farms in Algeria. Vet. World, 5(12): 709-712.

32. Talha, A. (2003) Investigation on the Prevalence of Mycoplasma gallisepticum in Village Chickens and Possibility of Establishing Mycoplasma gallisepticum Free Flocks and Significance of Mycoplasma gallisepticum on Different Production Parameters in Layer Chickens in Bangladesh. M. Sc. Thesis. Department of Veterinary Microbiology, the Royal Veterinary and Agricultural University, Denmark and Department of Pathology, Bangladesh Agricultural University, Mymensing, Bangladesh.

33. Whitford, H.W., Rosenbusch, R.F. and Lauerman, L.H. (1994) Mycoplasmosis in Animals: Laboratory Diagnosis. Iowa State University Press, Ames, IA.

34. Landman, W.J. (2014) Is Mycoplasma synoviae outrunning Mycoplasma gallisepticum? A viewpoint from the Netherlands. Avian Pathol., 43(1): 2-8.

35. Mukhtar, M., Awais, M.M., Anwar, M.I., Hussain, Z., Bhatti, N. and Ali, S. (2012) Seroprevalence of Mycoplasma gallisepticum among commercial layers in Faisalabad, Pakistan. J. Basic Appl. Sci., 8: 183-186.

36. Yegani, M. and Korver, D. (2010) Application of egg yolk antibodies as replacement for antibiotics in poultry. World Poult. Sci. J., 66(1): 27.

37. Qasem, J.A., Al-Mouqati, S.A., Al-Ali, E.M. and Ben-Haji, A. (2015) Application of molecular and serological methods for rapid detection of Mycoplasma gallisepticum infection (Avian mycoplasmosis). Pak. J. Biol. Sci., 18(2): 81.

38. Hammouda, A., Pearce-Duvet, J., Boulinier, T. and Selmi, S. (2014) Egg sampling as a possible alternative to blood sampling when monitoring the exposure of yellow-legged 
gulls (Larus michahellis) to avian influenza viruses. Avian Pathol., 43(6): 547-551.

39. Bonneaud, C., Balenger, S.L., Russell, A.F., Zhang, J., Hill, G.E. and Edwards, S.V. (2011) Rapid evolution of disease resistance is accompanied by functional changes in gene expression in a wild bird.Proc. Natl. Acad. Sci. U. S. Am., 108(19): 7866-7871.

40. David, S.A.W., Volokhov, D.V., Ye, Z. and Chizhikov, V. (2010) Evaluation of Mycoplasma inactivation during production of biologics: Egg-based viral vaccines as a model. Appl. Environ. Microbiol., 76(9): 2718-2728.

41. Hossain, K.M.M., Hossain, M.T. and Yamato, I. (2010) Seroprevalence of Salmonella and Mycoplasma gallisepticum infection in chickens in Rajshahi and surrounding districts of Bangladesh. Int. J. Biol., 2(2): 74.

42. Sikder, A., Islam, M., Rahman, M. and Rahman, M. (2005) Seroprevalence of Salmonella and Mycoplasma gallisepticum infection in the six model breeder poultry farms at Patuakhali district in Bangladesh. Int. J. Poult. Sci., 4(11): 905-910.

43. Arbelot, B., Doyen, J., Mamis, D., Gueye, J., Tati, F. and Samb, H. (1997) Enquête sur la prévalence sérologique des principales pathologies aviaires au Sénégal: Mycoplasmoses, pullorose, typhose, maladie de Newcastle, maladie de Gumboro et bronchite infectieuse $=$ Seroprevalence survey of dominant avian diseases in Senegal: Mycoplasmoses, fowl typhoid and pullorum disease, Newcastle, infectious bursal and infectious bronchitis diseases. Rev. Élev. Méd. Vét. Pays Trop., 50(3): 197-203.

44. Garcia, M., Jackwood, M., Levisohn, S. and Kleven, S. (1995) Detection of Mycoplasma gallisepticum, M. synoviae, and $M$. iowae by multi-species polymerase chain reaction and restriction fragment length polymorphism. Avian Dis., 39(3): 606-616.

45. Lauerman, L.H., Hoerr, F.J., Sharpton, A.R., Shah, S.M. and van Santen, V.L. (1993) Development and application of a polymerase chain reaction assay for Mycoplasma synoviae. Avian Dis., 37(3): 829-834.

46. Mardassi, B.B.A., Mohamed, R.B., Gueriri, I., Boughattas, S. and Mlik B. (2005) Duplex PCR to differentiate between Mycoplasma synoviae and Mycoplasma gallisepticum on the basis of conserved species-specific sequences of their hemagglutinin genes. J. Clin. Microbiol., 43(2): 948-958.

47. Ewing, M., Cookson, K., Phillips, R., Turner, K. and Kleven, S. (1998) Experimental infection and transmissibility of Mycoplasma synoviae with delayed serologic response in chickens. Avian Dis., 42: 230-238.

48. May, M., Dunne, D.W. and Brown, D.R. (2014) A sialoreceptor binding motif in the Mycoplasma synoviae adhesin VlhA. PloS One, 9(10): e110360.

49. Ansari, H., Pourbakhsh, S., Sheikhi, N., Bozorgmehri, F.M. and Ashtari, A. (2010) Detection of Mycoplasma synoviae by vlha-PCR with special primers in clinical sample. Vet. Clin. Pathol., 3(4): 673-682. 